\title{
PENGARUH DIVERSITAS \\ KEBANGSAAN BOARD OF DIRECTOR DAN KEPEMILIKAN BLOCKHOLDERS TERHADAP NILAI PERUSAHAAN: STUDI PADA PERUSAHAAN PUBLIK DI INDONESIA
}

\author{
Feby Astrid Kesaulya ${ }^{1}$, Novita Febriany ${ }^{2}$ \\ Universitas Katolik Musi Charitas \\ feby@ukmc.ac.id'1 ,novita@ukmc.ac.id ${ }^{2}$
}

\begin{abstract}
The purpose of this study is analyze the influence of the implementation of good corporate governance to the value of the company. The implementation of corporate governance in this study is represented by the nationality diversity of board of directors and ownership of blockholders. The nationality diversity of the board of directors in this study is represented by foreign board of directors, foreign board of commissioners, and foreign CEO / CFO. This study was conducted on Indonesian public corporations using 363 firm years sample. The results of this study show different results from previous studies. This study shows that the implementation of good corporate governance in the form of nationality diversity board of directors measured using foreign board of directors, foreign board of commissioners and foreign CFO / CEO does not affect the value of the company. In addition, ownership of blockholders also has no effect on the value of the company.
\end{abstract}

Keywords: nationality diversity of board of directors, blockholders ownership, company's value

\begin{abstract}
ABSTRAK
Tujuan dari penelitian ini adalah menganalisis pengaruh penerapan tata kelola perusahaan yang baik terhadap nilai perusahaan. Implementasi tata kelola perusahaan dalam penelitian ini diwakili oleh keanekaragaman kebangsaan dewan direksi dan kepemilikan blockholder. Keragaman kebangsaan dari dewan direksi dalam penelitian ini diwakili oleh dewan direksi asing, dewan komisaris asing, dan CEO / CFO asing. Penelitian ini dilakukan pada perusahaan publik Indonesia menggunakan sampel 363 tahun perusahaan. Hasil penelitian ini menunjukkan hasil yang berbeda dari penelitian sebelumnya. Penelitian ini menunjukkan bahwa penerapan tata kelola perusahaan yang baik dalam bentuk kebangsaan dewan direksi diukur menggunakan dewan direksi asing, dewan
\end{abstract}


komisaris asing dan CFO / CEO asing tidak mempengaruhi nilai perusahaan. Selain itu, kepemilikan blockholder juga tidak berpengaruh pada nilai perusahaan.

Kata kunci: keanekaragaman kebangsaan direksi, kepemilikan blockholder, nilai perusahaan

\section{PENDAHULUAN}

Pada tahun 2015 pemerintah Indonesia melakukan pengesahan MEA (Masyarakat Ekonomi ASEAN). Pengesahan MEA 2015 membuka peluang bagi seluruh masyarakat Indonesia khususnya dibidang ekonomi untuk dapat lebih mudah melakukan akses ke luar negeri begitu juga masyarakat dari luar negeri akan lebih mudah masuk ke Indonesia.

Hal ini dapat dilihat dari meningkatnya jumlah tenaga kerja asing di Indonesia, jumlah tenaga kerja asing (TKA) yang berada di Indonesia hingga November 2016 mancapai 74.183 pekerja yang meningkat $7.5 \%$ dari posisi akhir yaitu 69.025 pekerja. Selain itu semenjak izin mempekerjakan tenaga kerja asing (IMTKA) yang dikeluarkan Kementrian Tenaga Kerja dan Transmigrasi, Indonesia telah mengimpor 2.568 direksi dan 408 komisaris dari luar negeri. Banyaknya perusahaan asing di Indonesia dan perusahaan lokal maupun campuran yang menggunakan direksi dan komisaris dari luar negeri membuat jumlah tenaga kerja asing (TKA) pada tahun 2016 di dua level jabatan ini meningkat menjadi 13.080 pekerja dibanding tahun 2015 sebanyak 10.104 pekerja. Dengan meningkatnya jumlah dewan komisaris dan direksi dengan kebangsaan asing menunjukkan bahwa perusahaan sudah terbuka terhadap informasi dalam jejaring internasional.

Banyaknya tenaga kerja asing yang masuk juga dapat memberikan pengaruh terhadap pelaksanaan tata kelola perusahaan. Hal ini disebabkan oleh permasalahan diversitas dewan dan kode etik perusahaan juga dipertimbangkan ketika menilai keefektifan dari pembuatan keputusan perusahaan dan juga dipandang sebagai indikator independensi dan akuntabilitas pembuatan keputusan, keputusan yang baik akan mengarahkan kepada kemampuan menghasilkan laba yang lebih tinggi.

Keragaman dewan komisaris merupakan "good news" bagi investor karena investor mempunyai argumentasi bahwa adanya independensi dan terbukanya perusahaan menerima informasi dalam jejaring internasional sehingga akan meningkatkan nilai perusahaan. Teori sinyal didasarkan karena adanya masalah kesenjangan informasi atau ketidaksamaan akses terhadap informasi. Salah satu cara yang dilakukan untuk menghilangkan akses ini adalah pihak perusahaan memberikan sinyal dengan mengungkapan informasi yang relevan terhadap pihak lain yang membutuhkan informasi. Salah satu sinyal yang diberikan adalah perusahaan mengungkapkan informasi mengenai prinsip tata kelola perusahaan yang baik. Informasi ini akan memberikan sinyal yang baik dan memiliki 
information content bagi pihak yang berkepentingan sehingga akan berpengaruh terhadap penilaian perusahaan.

Menurut Wardani (2008) struktur dewan dalam perusahaan di Indonesia menganut sistem two-trier, yakni terdiri dari dewan direksi sebagai pengelola dan dewan komisaris sebagai pihak yang melakukan pengawasan. Dengan adanya anggota dewan komisaris dan direksi dengan kebangsaan asing merupakan salah satu ukuran diversitas dewan. Dewan komisaris dan direksi yang memiliki akses secara langsung kepada para investor akan memberikan keyakinan dalam penanaman modal saham dalam perusahaan. Pemikiran investor jika dalam suatu perusahaan terdapat dewan direksi berkebangsaan asing maka perusahaan tersebut dikelola oleh dewan direksi berkebangsaan asing akan memperlihatkan bahwa perusahaan telah dikelola secara profesional, sehingga para investor asing tidak ragu untuk menanam modal dalam perusahaan.

Selain diversitas kebangsaan yang mempengaruhi nilai perusahaan, kepemilikan blockholders salah satu variabel yang berpengaruh terhadap nilai perusahaan. Kepemilikan blockholder dapat meminimalkan residual lost dari agency problem. Berdasarkan teori agency adanya kepentingan yang berbeda antara pemilik dan agent. Manajemen sebagai pengelola perusahaan mempunyai kepentingan yang berbeda dengan pemegang saham, manajemen mengharapkan bonus yang tinggi atas kinerja sedangkan pemegang saham menginginkan laba yang tinggi. Manajemen dituntut untuk mengoptimalkan kemakmuran pemegang saham dengan memaksimumkan laba, hal ini dikenal dengan agency problem. Menurut Berle dan Means (1932) dalam Ariyani (2012), apabila struktur kepemilikan semakin tersebar, para pemegang saham akan semakin kehilangan power untuk melakukan control terhadap manjemen. Dengan adanya agency problem, kepentingan pemilik dan manajemen tidak selalu sejalan, maka manajemen dalam menggunakan sumber daya perusahaan menjadi tidak efisien dan membuat kinerja perusahaan menjadi rendah.

Salah satu cara untuk mengatasi masalah ini adalah dengan adanya kepemilikan Blockholder. Blockholder dapat meminimalkan residual lost dari agency problem ketika blockholder mempunyai preferensi yang kuat untuk mempertahankan kontrol terhadap perusahaan, Blockholder dapat didefinisikan sebagai kepemilikan manajerial, manajemen memiliki saham sekurang-kurangnya 5\% dari perusahaan. Ketika manajemen diposisikan sebagai pemegang saham, manajemen akan bertindak hati-hati dalam pengambilan keputusan sehingga kepentingan antara manajemen dan pemegang saham menjadi sejajar dan hal ini akan mengurangi masalah keagenan dan meningkatkan nilai perusahaan.

Masalah yang ingin dijawab dalam penelitian ini adalah apakah terdapat pengaruh diversitas kebangsaan board of director dan kepemilikan blockholders terhadap nilai perusahaan pada perusahaan publik di Indonesia. Penelitian ini diharapkan dapat memberikan kontribusi baik dari aspek literatur maupun secara praktek. Kontribusi penelitian ini terhadap literatur adalah penelitian ini dapat menambah pemahaman tentang tata kelola perusahaan khususnya komposisi 
dewan direksi dan kualitas komite audit dalam sebuah perusahaan sebagai mekanisme penting untuk memonitoring kegiatan perusahaan terutama dalam proses pembuatan laporan keuangan untuk menghindari praktek manajemen laba yang merugikan. Selain itu penelitian ini juga diharapkan dapat memperluas literatur tentang corporate governance. Kontribusi penelitian ini terhadap praktek adalah bahwa penelitian ini diharapkan dapat memberikan informasi bagi para manajer, pemilik perusahaan dan investor dalam hal pengambilan keputusan investasi dalam perusahaan.

\section{TINJAUAN PUSTAKA DAN PENGEMBANGAN HIPOTESIS}

\section{A. Teori Agensi}

Teori yang digunakan dalam penelitian ini adalah teori agensi yang dikemukakan oleh Jensen dan Meckling (1976). Tricker (2009) mengungkapkan bahwa teori agensi memandang praktek tata kelola perusahaan melalui pandangan tentang agency dilemma. Teori tersebut memandang bahwa hubungan tata kelola perusahaan sebagai kontrak antara principal, dalam hal ini pemegang saham, dan agen, dalam hal ini manajer atau direktur.

Menurut Watts dan Zimmerman (1990) dalam Kusumaningtyas (2012) menyatakan bahwa teori agensi disebabkan adanya informasi yang tidak seimbang yang disebut asimetri informasi (information asymmetry). Pada dasarnya teori keagenan yang menjelaskan tentang kepentingan manajemen dan kepentingan pemegang saham seringkali bertentangan, sehingga bisa terjadi konflik. Konflik keagenan yang terjadi bisa dikurangi dengan cara melakukan tata kelola perusahaan yang baik yaitu dengan cara pengungkapan yang lebih luas, sehingga asimetri informasi menjadi semakin kecil. Dengan kinerja yang baik, maka akan memicu perusahaan untuk melakukan tanggung jawab sosial dan melakukan pengungkapan yang lebih luas.

Menurut Paulina (2015) terkait dengan nilai perusahaan, teori ini mengatakan adanya keterkaitan antara pemegang saham dengan agen atau dalam penelitian ini yaitu anggota dewan komisaris dan direksi perusahaan. Dewan direksi perusahaan bertanggungjawab penuh atas keberlangsungan hidup perusahaan, sehingga akan berusaha menunjukkan nilai perusahaan yang tinggi agar para pemegang saham tidak melepaskan investasinya dalam perusahaan.

Salah satu cara yang dapat dilakukan untuk mengurangi hal ini adalah dengan adanya sistem monitoring yang baik dari principal. Mekanisme tata kelola perusahaan dianggap sebagai salah satu sistem monitoring yang cukup baik untuk bisa memitigasi sifat oportunistik manajer. Baysinger dan Hoskisson (1990) berpendapat bahwa berdasarkan teori agensi, mekanisme tata kelola perusahaan melalui dewan direksi akan memiliki otoritas secara legal untuk mempekerjakan, memberhentikan dan memberikan kompensasi kepada manajemen serta berperan penting dalam menjaga investasi modal. 
Maka dari itu, mekanisme tata kelola merupakan elemen yang penting dalam tata kelola perusahaan yang baik.

\section{B. Corporate Governance}

Meier (2005) menyatakan, tata kelola perusahaan yang baik bertujuan untuk memberikan dorongan kepada dewan (board) dan manajemen untuk mencapai tujuan tersebut, yang merupakan kepentingan perusahaan dan pemegang sahamnya. Wardani (2008), menyatakan bahwa kebanyakan definisi board of director (BOD) yang dimaksudkan dalam penelitian di luar negeri mengacu kepada one-tier system. Pada sistem ini BOD memiliki fungsi pengawasan terhadap kinerja manajemen. Paulina (2015) menyatakan bahwa di Indonesia menganut two-tier system, yang memisahkan peranan direksi sebagai pengelola dan komisaris sebagai pengawas.

Berdasarkan UU PT Nomor 40 Tahun 2007 dikatakan bahwa dewan komisaris bertugas untuk melakukan pengawasan atas kebijakan pengurusan, jalannya pengurusan pada umumnya, baik mengenai Perseroan maupun usaha Perseroan, dan memberi nasihat kepada dewan direksi. Komite audit yang berlatar belakang pendidikan akuntansi dan keuangan akan membantu dewan komisaris dalam menjalankan tugasnya dengan baik.

\section{Pengembangan Hipotesis}

\section{Dewan Komisaris Asing dan Nilai Perusahaan}

Menurut Komite Nasional Kebijakan Corporate Governance (KNKCG) (2001) dewan komisaris adalah organ perusahaan yang bertugas dan bertanggung jawab secara kolektif untuk melakukan pengawasan dan memberikan nasihat kepada direksi serta memastikan bahwa perusahaan melaksanakan Good Corporate Governance. Berdasarkan UU PT Nomor 40 Tahun 2007, tujuan keberadaan dewan komisaris adalah melakukan pengawasan atas jalannya usaha dan memberikan nasihat kepada direksi. Secara tidak langsung tugas tersebut akan memberikan pengaruh terhadap kualitas laba yang dilaporkan oleh perusahaan karena dewan komisaris dapat mengarahkan kebijakan dan tindakan CEO dan CFO terkait dengan pelaporan keuangan. Keunggulan perusahaan apabila memiliki anggota dewan berkebangsaan asing adalah adanya pengalaman industri yang lebih luas, serta pencitraan oleh pasar yang menilai bahwa perusahaan dengan anggota dewan asing bekerja secara professional (Randoy dan Oxelheim, 2001). Pengalaman dan pencitraan tersebut dapat menarik minat investor untuk menanamkan saham pada perusahaan. Semakin besar investor menanamkan saham, maka nilai perusahaan akan ikut meningkat.

Penelitian yang dilakukan di Netherlands dan Switzerland oleh Ruigrok dan Kaczmarek (2008) dalam Darmadi (2010), ditemukan 
pengaruh positif diversitas kebangsaan anggota dewan komisaris terhadap kinerja keuangan perusahaan. Randoy dan Oxelheim (2001) di Swedia dan Norwegia juga ditemukan pengaruh positif diversitas kebangsaan komisaris terhadap nilai perusahaan. Penelitian Ararat et al., (2010) pada perusahaan-perusahaan di Turkish, menemukan pengaruh positif diversitas kebangsaan anggota dewan terhadap nilai perusahaan. Sehingga diajukan hipotesis sebagai berikut:

H1: Semakin banyak anggota dewan komisaris asing dalam perusahaan akan menghasilkan nilai perusahaan yang semakin tinggi.

\section{Dewan Direksi Asing dan Nilai Perusahaan}

Menurut Paulina (2015), Dewan direksi bertanggungjawab atas jalannya perusahaan, pencapaian tujuan perusahaan, pelaporan keuangan perusahaan, dan menerima nasihat yang diberikan oleh anggota dewan komisaris. Dengan perbedaan latar belakang dan wewenang yang dimiliki, dewan direksi asing bisa menambah pengalaman yang lebih beragam dan berharga, yang tidak dimiliki oleh dewan direksi domestik.

Randoy dan Oxelheim (2001) menyatakan adanya pengaruh positif diversitas kebangsaan anggota dewan direksi pada perusahaan di Norwegia dan Swedia terhadap nilai perusahaan. Ararat et al. (2010) melakukan penelitian pada perusahaan-perusahaan di Turkish dan menemukan pengaruh positif diversitas kebangsaan anggota dewan terhadap nilai perusahaan. Choi et al. (2007) mengatakan adanya pengaruh positif diversitas anggota dewan terhadap kinerja keuangan pada perusahaan-perusahaan di Korea. Oleh karena itu, dalam penelitian ini diajukan hipotesis sebagai berikut :

H2: Semakin banyak anggota dewan direksi asing dalam perusahaan akan menghasilkan nilai perusahaan yang semakin tinggi.

\section{CEO atau CFO Asing dan Nilai Perusahaan}

Menurut Paulina (2015), CEO (Chief Executive Officer) adalah jabatan tertinggi dalam perusahaan yang memiliki tanggung jawab untuk mengatur seluruh kegiatan perusahaan. CEO merupakan eksekutif yang berada dipuncak perusahaan dan yang bertanggung jawab untuk kelangsungan hidup dan keberhasilan perusahaan (Dewi, 2013). Menurut Paulina (2015) CFO (Chief Financial Officer) adalah jabatan di suatu perusahaan yang memiliki tanggung jawab utama untuk mengelola risiko keuangan perusahaan.

Dengan tugas dan wewenang yang dimiliki, seorang CEO ataupun CFO memiliki kebebasan untuk menentukan kegiatan operasional yang akan dijalankan oleh perusahaan (Paulina: 2015). Seorang dewan direksi berkebangsaan asing dinilai dapat lebih meyakinkan pihak investor untuk 
dapat menanamkan modal saham di perusahaan (Randoy dan Oxelheim, 2001). Dengan pengalaman industri yang luas serta didukung dengan pencitraan yang mengatakan perusahaan dengan anggota asing lebih professional, kelebihan tersebut akan mempengaruhi minat para investor untuk menanamkan saham pada perusahaan. Semakin tinggi nilai saham yang ditanamkan investor didalam perusahaan, maka akan meningkatkan nilai perusahaan. Secara tidak langsung dapat memperkuat dugaan bahwa seorang CEO memiliki wewenang penuh dalam mengoperasikan perusahaan, apabila CEO berkebangsaan asing dimungkinkan akan meningkatkan citra perusahaan dengan cara meningkatkan pertumbuhan nilai perusahan. Dalam penelitian Dewi (2013) menemukan adanya pengaruh peran CEO terhadap kinerja perusahaan. Trisnantari (2012) dalam penelitiannya menemukan adanya pengaruh positif dan signifikan pergantian CEO dengan kinerja perusahaan. Dengan demikian, diajukan hipotesis sebagai berikut :

H3: Keberadaan CEO atau CFO asing dalam perusahaan akan berpengaruh positif terhadap nilai perusahaan.

\section{Kepemilikan Blockholders dan Nilai Perusahaan}

Jensen dan Meckling (1976) didalam Ariyani (2012) menyebutkan bahwa kepemilikan manajerial dapat meningkatkan kinerja perusahaan karena kepentingan antara manajemen dan pemegang saham menjadi sejajar. Semakin besar kepemilikan manajerial maka semakin kecil keinginan manajemen untuk menyalahgunakan sumber daya dari value maximization (Berle dan Means, 1932) dalam Ariyani (2012).

Penelitian Ariyani (2008) menyatakan bahwa adanya pengaruh yang positif antara nilai perusahaan terhadap blockholder ownership. Myers and Majluf (1984) dalam Ariyani (2012) juga menyatakan bahwa dalam hipotesis Pecking-order menunjukkan adanya pengaruh positif nilai perusahaan terhadap blockholder. Dengan demikian, diajukan hipotesis sebagai berikut :

H4: Kepemilikan blockholders di dalam perusahaan akan berpengaruh positif terhadap nilai perusahaan.

D. Kerangka Pemikiran

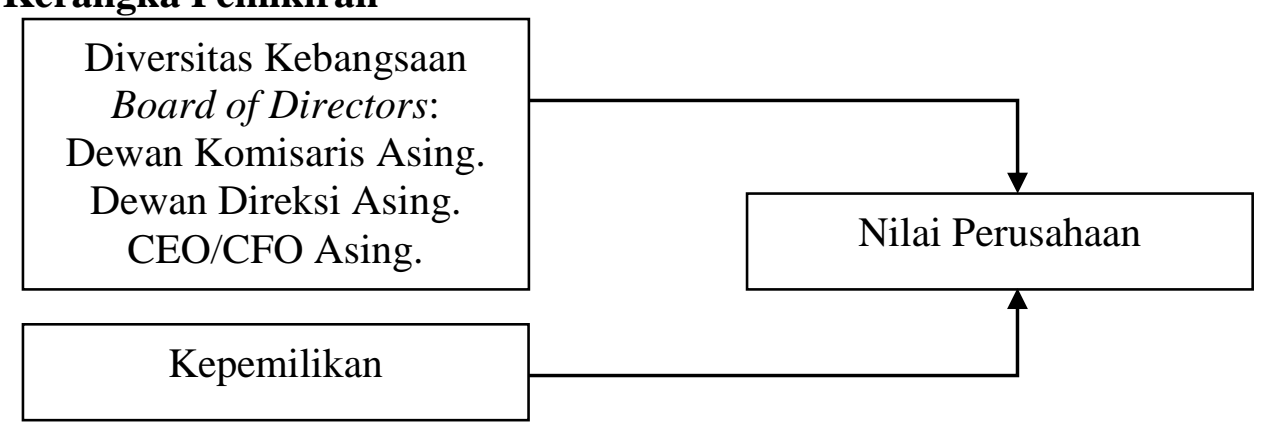

Gambar 1. Kerangka Pemikiran 


\section{METODE PENELITIAN}

\section{A. Jenis dan Sumber Data}

Jenis data yang digunakan dalam penelitian ini adalah data sekunder yaitu data yang diambil dari laporan tahunan perusahaan periode 2014 - 2016. Data dalam penelitian ini diambil dari laporan keuangan perusahaan yang terdaftar di BEI, Indonesian Capital Market Directory dan Galery Investasi Unika Musi Charitas Palembang.

\section{B. Populasi dan Sampel}

Populasi yang digunakan dalam penelitian ini adalah semua perusahaan manufaktur yang terdaftar di Bursa Efek Indonesia. Sedangkan pemilihan sampel dalam penelitian ini adalah dengan menggunakan metode purposive sampling dengan kriteria berikut :

1. Perusahaan manufaktur yang terdaftar di BEI (IDX) pada periode penelitian yaitu tahun 2014-2016.

2. Perusahaan yang menggunakan mata uang rupiah dalam penyajian laporan keuangan perusahaannya

3. Perusahaan yang memberikan data mengenai riwayat hidup anggota komisaris dan direksi

\section{Metode Pengumpulan Data}

Metode pengumpulan data yang digunakan dalam penelitian ini adalah menggunakan studi pustaka yaitu suatu cara memperoleh data dengan cara membaca, mempelajari buku-buku yang berhubungan dengan masalah yang dibahas.

\section{Definisi Operasional dan Pengukuran Variabel}

\section{Variabel Dependen}

Variabel dependen dalam penelitian ini adalah Nilai Perusahaan. Nilai perusahaan dalam penelitian ini diukur dengan menggunakan nilai pasar.Hal ini dikarenakan nilai perusahaan dapat memberikan kemakmuran pemegang saham secara maksimum apabila harga saham perusahaan meningkat. Semakin tinggi harga saham, maka akan semakin tinggi kemakmuran pemegang saham. Untuk mencapai nilai perusahaan yang tinggi para pemegang saham menyerahkan pengelolaan perusahaan kepada para professional dan diposisikan sebagai manajemen dalam perusahaan.

Rasio yang digunakan dalam menilai nilai perusahaan adalah dengan Tobin's Q. Semakin besar nilai rasio Tobin's Q menunjukkan bahwa perusahaan memiliki prospek pertumbungan yang baik dan memiliki intangible asset yang semakin besar. Hal ini terjadi karena 
semakin besar nilai pasar asset perusahaan maka semakin besar kerelaan investor untuk mengeluarkan pengorbanan yang lebih dalam memiliki perusahaan tersebut.

Pengukuran nilai perusahaan dengan menggunakan Tobin's Q ditunjukkan dalam persamaan berikut :

$$
\begin{gathered}
\text { TOBIN }=(\text { MVE }+ \text { DEBT }) / \text { TA } \\
\text { MVE }=\text { P x Qshares } \\
\text { DEBT }=(\text { CL }- \text { CA })+\text { INB }+ \text { LTL }
\end{gathered}
$$

Keterangan:

MVE = Nilai pasar dari jumlah lembar saham beredar

DEBT = Nilai total kewajiban perusahaan

TA = Nilai buku dari total aktiva perusahaan

$\mathrm{P} \quad=$ Harga saham penutupan akhir tahun

Qshares = Jumlah saham beredar akhir tahun

$\mathrm{CL}=$ Kewajiban jangka pendek

$\mathrm{CA}=$ Aktiva lancar

INV = Nilai buku persediaan

LTL = kewajiban jangka panjang

\section{Variabel Independen}

\section{a. Dewan Komisaris Asing}

Dewan komisaris dalah organ perusahaan yang bertugas dan bertanggung jawab secara kolektif untuk melakukan pengawasan dan memberikan nasihat kepada direksi serta memastikan bahwa perusahaan melaksanakan GCG dengan maksimal. Pengukuran dewan komisaris asing dihitung dengan cara jumlah komisaris asing dalam perusahaan dibagi dengan total komisaris yang ada dalam perusahaan.

\section{b. Dewan Direksi Asing}

Dewan direksi bertanggung jawab atas jalannya perusahaan, pencapaian tujuan, pelaporan keuangan perusahaan dan menerima nasihat yang diberikan oleh anggota dewan komisaris,

Dengan adanya dewan direksi berkebangsaan asing diharapkan perusahaan dapat menambah pengalaman dan wawasan yang lebih beragam yang tidak dimiliki oleh dewan direksi domestik. Pengukuran yang digunakan untuk mengukur jumlah dewan direksi 
asing adalah umlah direksi asing dalam perusahaan dibagi dengan total direksi yang ada dalam perusahaan.

c. CEO atau CFO Asing

CEO (Chief Executive Officer) adalah jabatan tertinggi dalam perusahaan yang memiliki tanggung jawab untuk mengatur seluruh kegiatan perusahaan. CEO bertanggung jawab penuh atas pengurusan dan jalannya perusahaan. CEO merupakan eksekutif yang berada dipuncak perusahaan dan yang bertanggung jawab untuk kelangsungan hidup dan keberhasilan perusahaan (Dewi 2013). Pengukuran yang digunakan untuk mengukur CEO atau $\mathrm{CFO}$ asing adalah dengan menggunakan variabel dummy, apabila CEO atau CFO asing maka diberi skor 1, apabila tidak terdapat $\mathrm{CEO}$ atau $\mathrm{CFO}$ asing maka diberi skor 0

\section{d. Kepemilikan Blockholders}

Blockholder dapat didefinisikan sebagai kepemilikan manajerial, manajemen memiliki saham sekurang-kurangnya 5\% dari perusahaan. Ketika manajemen diposisikan sebagai pemegang saham, manajemen akan bertindak hati-hati dalam pengambilan keputusan sehingga kepentingan antara manajemen dan pemegang saham menjadi sejajar dan hal ini akan mengurangi masalah keagenan dan meningkatkan nilai perusahaan. Blockholder didefinisikan sebagai pemegang saham yang memiliki sekurang-kurangnya 5\% saham perusahaan. Pengukuran kepemilikan blockholder adalah:

$$
\text { oS }=\frac{\text { Presentase total kepemilikan blockholders }}{100-\text { Presentase total kepemilikan blockholders }}
$$

\section{E. Model Regresi Linier Berganda}

$\mathrm{Y}=\alpha+\mathrm{bX} 1+\mathrm{bX} 2+\mathrm{bX} 3+\mathrm{bX} 4+\mathrm{e}$

Keterangan:

$\mathrm{Y}=$ Nilai Perusahaan

$\mathrm{X} 1=$ Dewan Komisaris Asing

$\mathrm{X} 2=$ Dewan Direksi Asing

$\mathrm{X} 3=\mathrm{CEO}$ atau CFO Asing

X4= Kepemilikan Blockholders

$\mathrm{e}=$ error

\section{F. Pengujian Asumsi Klasik}

Pengujian asumsi klasik bertujuan untuk mengetahui dan menguji kelayakan atas model regresi yang digunakan untuk penelitian ini. Pengujian ini juga dimaksud untuk memastikan bahwa didalam model regresi yang digunakan tidak terdapat masalah asumsi klasik seperti normalitas, autokolerasi, heteroskedastisitas dan multikolinearitas. 


\section{G. Uji Hipotesis}

Uji statistik t menunjukkan seberapa jauh pengaruh variabel bebas secara individual dalam menerangkan variabel terkait (Ghozali, 2006). Dasar pengambilan keputusan adalah:

a. Jika t-hitung < t-tabel, maka variabel bebas secara individual tidak berpengaruh terhadap variabel terikat (hipotesis ditolak).

b. Jika t-hitung > t-tabel, maka variabel bebas secara individual berpengaruh terhadap variabel terikat (hipotesis diterima).

Uji t dapat juga dilakukan dengan melihat nilai signifikansi t masingmasing variabel pada output hasil regresi menggunakan SPSS dengan Significance level 0.05 (a=5\%). Jika sig >0.05 maka hipotesis ditolak tetapi jika sig $<0.05$ maka hipotesis diterima.

\section{HASIL PENGUJIAN HIPOTESIS}

\section{A. Data Penelitian}

Tabel 1. Data Penelitian

\begin{tabular}{lc}
\hline \multicolumn{1}{c}{ Keterangan } & Jumlah (firm years) \\
\hline Data (Obervasi) Penelitian Awal & 336 \\
Dikurangi: outlier & $(3)$ \\
Data (Observasi) akhir & 333 \\
\hline
\end{tabular}

Data awal yang diperoleh pada penelitian ini adalah sebanyak 336 firm years. Data tersebut didapatkan dari Bursa Efek Indonesia berupa perusahaan manufaktur yang terdaftar di BEI. Setelah dilakukan pengujian outlier maka terdapat 3 data yang dikeluarkan dari observasi. Maka dari itu, data observasi akhir yang digunakan untuk pengujian adalah sebanyak 333 firm years.

\section{B. Uji Normalitas Awal}

Tabel 2. Hasil Uji Normalitas

\begin{tabular}{ccc}
\hline Test Statistic & Signifikansi & Keterangan \\
\hline $\mathbf{0 , 3 6 7}$ & 0,000 & Tidak Berdistribusi Normal \\
\hline
\end{tabular}

Berdasarkan hasil pengujian 1-sample Kolmogorov-Smirnov didapatkan hasil signifikansi untuk normalitas residual adalah sebesar 0,000. Nilai ini lebih rendah dari 0,05 sehingga dapat disimpulkan bahwa residual pada penelitian ini tidak terdistribusi normal. 


\section{Uji Hipotesis dengan Metode Bootstrap}

Tabel 3. Hasil Uji Hipotesis

\begin{tabular}{crrc}
\hline Variabel & T hitung & Sig. & Keterangan \\
\hline Dewan Komisaris Asing & 0,284 & 0,777 & H1 tidak terdukung \\
Dewan Direksi Asing & $-0,358$ & 0,720 & H2 tidak terdukung \\
CEO atau CFO Asing & 1,398 & 0,163 & H3 tidak terdukung \\
Kepemilikan Blockholders & $-0,064$ & 0,949 & H4 tidak terdukung \\
\hline
\end{tabular}

Hipotesis dalam penelitian ini diuji dengan metode bootstrap hal ini dikarenakan data serta residual data dalam penelitian ini tidak berdistribusi normal. Metode bootstrap sendiri adalah metode statistik non-parametrik berbasis resampling data sampel dengan syarat pengembalian pada datanya dalam menyelesaikan statistik ukuran suatu sampel dengan harapan sampel tersebut mewakili data populai sebenarnya, biasanya ukuran resampling diambil secara ribuan kali agar dapat mewakili data populasinya. Bootstrap memungkinkan seseorang untuk melakukan inferensi statistik tanpa membuat asumsi distribusi yang kuat dan tidak memerlukan formulasi analitis untuk distribusi sampling suatu estimator. Sebagai pengganti, bootstrap menggunakan distribusi empiris untuk mengestimasi distribusi sampling.

Berdasarkan pengujian regresi berganda dengan metode bootstrap, didapatkan hasil bahwa nilai t hitung dari variabel diversitas kebangsaan board of directors yang diwakili oleh dewan komisaris asing, dewan direksi asing, dan CEO atau CFO asing serta variabel kepemilikan blockholders atau kepemilikan keluarga lebih kecil daripada t tabel, yaitu masing-masing sebesar 0,284, -0,358, 1,398, dan -0,064. Selain itu nilai signifikansi untuk masing-masing variabel independen juga lebih besar daripada 0,05 yaitu 0,777, 0,720, 0,163 dan 0,949. Sehingga dapat disimpulkan bahwa keempat variabel independen, yaitu dewan komisaris asing, dewan direksi asing, CEO atau CFO asing, dan kepemilikan blockholders tidak memiliki pengaruh terhadap nilai perusahaan yang diukur menggunakan Tobin's Q. Oleh karena itu, H1, H2, H3, dan $\mathrm{H} 4$ penelitian ini tidak terdukung.

Dari hasil pengujian hipotesis didapatkan bahwa tidak terdapat pengaruh antara diversitas kebangsaan board of directors yang dalam hal ini diproksikan oleh dewan komisaris asing, dewan direksi asing dan CEO/CFO asing. Hasil penelitian ini tidak sejalan dengan Randoy dan Oxelheim (2001) serta Ararat et al., (2010) yang menemukan bahwa terdapat pengaruh positif dari diversitas kebangsaan dewan komisaris terhadap nilai perusahaaa di Swedia dan Norwegia juga Turki. Hasil ini juga tidak sejalan dengan penelitian Choi et al. (2007) yang menyatakan bahwa terdapat pengaruh positif diversitas anggota dewan terhadap kinerja keuangan pada perusahaanperusahaan di Korea. Hasil ini pun berbeda dengan penelitian Dewi (2013) yang menemukan adanya pengaruh peran CEO terhadap kinerja perusahaan. 
Hasil pengujian hipotesis juga menunjukkan tidak adanya dukungan terhadap hipotesis bahwa kepemilikan blockholders berpengaruh positif terhadap nilai perusahaan. Hasil ini tidak sejalan dengan penelitian Ariyani (2012) yang menemukan bahwa ada pengaruh positif nilai perusahaan terhadap kepemilikan blockholder.

Adanya sistem tata kelola perusahaan diharapkan dapat meningkatkan kualitas pelaporan keuangan di mata investor sehingga dapat meningkatkan nilai perusahaan. Hal ini dikarenakan pengawasan yang dilakukan akan lebih efektif dan bisa mengurangi sifat oportunistik dari para manajer. Secara umum penelitian-penelitian sebelumnya juga telah mengindikasikan bahwa sistem tata kelola perusahaan yang baik dapat menjadi meningkatkan nilai perusahaan di mata investor.

\section{KESIMPULAN, KETERBATASAN DAN SARAN}

\section{A. Kesimpulan}

Penelitian ini ingin menguji hubungan antara nilai perusahaan dan tata kelola perusahaan di Indonesia. Dihipotesiskan bahwa tata kelola perusahaan yang efektif dapat meningkatkan nilai perusahaan. Variabel tata kelola perusahaan dalam penelitian ini diproksikan oleh diversitas kebangsaan board of directors yang diukur menggunakan tiga pengukuran yaitu dewan komisaris asing, dewan direksi asing, dan CEO atau CFO asing. Selain itu variabel tata kelola perusahaan juga diproksikan oleh kepemilikan blockholders. Nilai perusahaan dalam penelitian diukur menggunakan Tobin's Q.

Setelah dilakukan pengujian hipotesis, Hasil penelitian ini menemukan bahwa:

1. Hipotesis 1 yang menyatakan bahwa semakin banyak anggota dewan komisaris asing dalam perusahaan akan menghasilkan nilai perusahaan yang semakin tinggi tidak terdukung.

2. Hipotesis 2 yang menyatakan bahwa semakin banyak anggota dewan direksi asing dalam perusahaan akan menghasilkan nilai perusahaan yang semakin tinggi tidak terdukung.

3. Hipotesis 3 yang menyatakan bahwa keberadaan CEO atau CFO asing dalam perusahaan akan berpengaruh positif terhadap nilai perusahaan tidak terdukung.

4. Hipotesis 4 yang menyatakan bahwa kepemilikan blockholders di dalam perusahaan akan berpengaruh positif terhadap nilai perusahaan tidak terdukung.

\section{B. Keterbatasan}

Keterbatasan dalam penelitian ini antara lain adalah terdapat beberapa asumsi klasik yang tidak terpenuhi dalam pengujian sehingga terdapat keterbatasan dalam menyimpulkan hasil dari penelitian ini. 


\section{Saran}

Saran yang dapat diberikan untuk penelitian selanjutnya adalah:

1. Penelitian ini dapat dilakukan dalam konteks akuntansi internasional bila database terkait dengan hal tersebut tersedia.

2. Penelitian ini dapat menggunakan proksi lain dalam mengukur corporate governance.

\section{REFERENSI}

Ararat, Melsa., Mine Aksu, and Ayse T. Cetin. 2010. Impact of Board Diversity on Boards Monitoring Intensity and Firm Performance: Evidence from the Istambul Stock Exchange. Available at: http://ssrn.com/abstract $=1572283$.

Ariyani, Vivi. 2012. Pengaruh Nilai Perusahaan Terhadap Kepemilikan Blockholder: Perusahaan di BEI 2005-2008. Widya Warta No.02 Tahun XXXV I/Juli 2012. ISSN 0854-1981.

Choi, J.J., Park, S.W. and Yoo, S.S. 2007. The value of outside directors: evidence from corporate governance reform in Korea. Journal of Financial and Quantitative Analysis, Vol. 42 No. 4, pp. 941-962.

Da Silveira, Alexandre Di Miceli and Lucas Ayres B. de C. Barros. 2007. Corporate Governance Quality and Firm Value in Brazil. Available at : http://ssrn.com/abstract $=923310$

Darmadi, Salim. 2010. Board diversity and firm performance: the Indonesian evidence. In: MPRA Paper. repec:pra:mprapa:38721.

Dewi, Karunia C. 2013. Pengaruh Pergantian CEO terhadap Kinerja Perusahaan dengan Manajemen Laba sebagai Variabel Intervening. Available at http://eprints.ums.ac.id/26975/24/02._Jurnal_Publikasi.docx.pdf.

Ghozali, I. 2006. Aplikasi Analisis Multivariat Dengan Program SPSS. Semarang: Badan Penerbit Universitas Diponegoro.

Komite Nasional Kebijakan Corporate governance (KNKCG). 2001. Pedoman Good Gorporate governance: Ref. 4. 0.

Kusumaningtyas, M. 2012. Pengaruh Independensi Komite Audit dan Kepemilikan Institusional Terhadap Manajemen Laba. Prestasi Vol. 9 No. 1 (Juni 2012): 41-60. 10

Kusumastuti, Sari, Supatmi, dan Perdana Sastra. 2006. Pengaruh Board Diversity terhadap Nilai Perusahaan dalam Perspektif Corporate 
Governance. Jurnal Ekonomi Akuntansi-UniversitasKristenPetra. Available at: http://puslit.petra.ac.id/journals/accounting.

Meier, S. 2005. How Global is Good Corporate Governance. Ethical Investment Research Services. Available at : http://www.eiris.org/files/research publication/howglobaliscorpgov05.pdf.

Pauline, Jayalaksmi Winoto, dan Supatmi. 2015. Pengaruh Diversitas Kebangsaan Board of Director Terhadap Nilai Perusahaan. UKSW

Ponnu, C.H. 2008. Academic Qualifications of Board of Directors and Company Performance. The Business Review Cam, bridge. Vol. 10. No.1: 177-181.

Randoy, T., and Oxelheim, L. 2001. The impact of foreign board membership on firm value. Working Paper, Research Institute of Industrial Economics (IUI), Sweden. Available at : http://www.ifn.se/wfiles/wp/WP567.pdf.

Sukamulja, Sukmawati. 2004. Good Corporate Governance di Sektor Keuangan: Dampak GCG Terhadap Kinerja Perusahaan (Kasus di Bursa Efek Jakarta). Benefit Jurnal Manajemen dan Bisnis 8.1 : 1-25.

Thomsen,S.,Pedersen,T.,Kvist,K.H,2006. Blockholder ownership : Effects on firm value in market and control based governance system. Journal of Corporate Finance 12 (2006),246-269

Undang-Undang Perseroan Terbatas Nomor 40, Tahun 2007 tentang Perseroan Terbatas. (https://www.legalitas.org/incl-php/buka.php, diakses tanggal 11 Mei 2017).

Wahyudi, Untung, dan Hartini Prasetyaning Pawestri. 2006. Implikasi struktur kepemilikan terhadap nilai perusahaan: dengan keputusan keuangan sebagai variabel intervening. Simposium Nasional Akuntansi 9 : 1-25.

Wardani, R. 2008. Pengaruh Konsentrasi Pemilikan, Ukuran Perusahaan, dan Mekanisme Corporate Governance terhadap Manajemen Laba. Makalah. Disampaikan dalam Simposium Nasional Akuntansi ke XI di Pontianak 2324 Juli. 